\title{
Response of Tomato (Solanum lycopersicum L.) Genotypes to Heat Stress Using Morphological and Expression Study
}

\author{
Abdulhakim A. Aldubai ${ }^{1}$, Abdullah A. Alsadon $\left.{ }^{1}{ }^{(}\right)$, Hussein H. Migdadi ${ }^{1,2}, * \mathbb{C}$, Salem S. Alghamdi ${ }^{1}(\mathbb{D}$, \\ Sulieman A. Al-Faifi ${ }^{1}$ and Muhammad Afzal ${ }^{1}$ (D) \\ 1 Department of Plant Production, College of Food and Agriculture Sciences, King Saud University, \\ Riyadh 11451, Saudi Arabia; hakimaldobai@gmail.com (A.A.A.); alsadon@ksu.edu.sa (A.A.A.); \\ salem@ksu.edu.sa (S.S.A.); salfaifi@ksu.edu.sa (S.A.A.-F.); mmushtaq@ksu.edu.sa (M.A.) \\ 2 National Agricultural Research Center, Baqa, Amman 19381, Jordan \\ * Correspondence: hmigdadi@ksu.edu.sa; Tel.: +966-535-871-345
}

check for updates

Citation: Aldubai, A.A.; Alsadon, A.A.; Migdadi, H.H.; Alghamdi, S.S.; Al-Faifi, S.A.; Afzal, M. Response of Tomato (Solanum lycopersicum L.) Genotypes to Heat Stress Using Morphological and Expression Study. Plants 2022, 11, 615. https://doi.org/ $10.3390 /$ plants 11050615

Academic Editors: Oleg Sergeevich Alexandrov and Shuji Yokoi

Received: 18 December 2021 Accepted: 18 February 2022 Published: 24 February 2022

Publisher's Note: MDPI stays neutral with regard to jurisdictional claims in published maps and institutional affiliations.

Copyright: (C) 2022 by the authors. Licensee MDPI, Basel, Switzerland. This article is an open access article distributed under the terms and conditions of the Creative Commons Attribution (CC BY) license (https:// creativecommons.org/licenses/by/ $4.0 /)$.

\begin{abstract}
Due to unfavorable environmental conditions, heat stress is one of the significant production restrictions for the tomato (Solanum lycopersicum L.) crop. The tomato crop is considered an important vegetable crop globally and represents a model plant for fruit development research. The heat shock factor (HSF) gene family contains plant-specific transcription factors (TFs) that are highly conserved and play a key role in plant high-temperature stress responses. The current study was designed to determine the relative response of heat stress under three different temperatures in the field condition to determine its relative heat tolerance. Furthermore, the study also characterized heat shock genes in eight tomato genotypes under different temperature regimes. The expressions of each gene were quantified using qPCR. The descriptive statistics results suggested a high range of diversity among the studied variables growing under three different temperatures. The qPCR study revealed that the SlyHSF genes play an important role in plant heat tolerance pathways. The expression patterns of HSF genes in tomatoes have been described in various tissues were determined at high temperature stress. The genes, SlyHSFs-1, SlyHSFs-2, SlyHSFs-8, SlyHSFs-9 recorded upregulation expression relative to SlyHSFs-3, SlyHSFs-5, SlyHSFs-10, and SlyHSFs-11. The genotypes, Strain B, Marmande VF, Pearson's early, and Al-Qatif-365 recorded the tolerant tomato genotypes under high-temperature stress conditions relative to other genotypes. The heat map analysis also confirmed the upregulation and downregulation of heat shock factor genes among the tomato genotypes. These genotypes will be introduced in the breeding program to improve tomato responses to heat stress.
\end{abstract}

Keywords: tomato; heat shock protein; transcription factor; expression; qPCR

\section{Introduction}

The tomato (Solanum lycopersicum L., $2 \mathrm{n}=24$ ) is a self-pollinated crop that belongs to the Solanaceae family, ranking second to potato in the world's vegetable production. In the Solanaceae family, there are more than 3000 different types of species [1], which includes the tomato, one of the world's most significant vegetables [2]. According to FAOSTAT [3], the total cultivated area by tomatoes around the world was estimated at around 5.8 million hectares with a production of 233.5 million tons. In Saudi Arabia, the devoted area to tomato production was 13.3 thousand hectares with average productivity of 23.01 tons per hectare. Heat stress or heat shock is defined as a temperature increase of $10-15{ }^{\circ} \mathrm{C}$ above the optimal temperature [4]. Heat stress is a multidimensional function that is determined by the rate of temperature rise and the total length of exposure [5]. In specific climatic zones, the intensity of heat stress is primarily influenced by the frequency of heat shock and the length of high day/night temperatures. Thermotolerance refers to a plant's ability to withstand exceptionally high or low temperatures while still producing a profit. According to reports, the tomato crop in some parts of the world is subjected to extreme 
temperatures regularly. Heat stress has a significant impact on tomato reproduction. High temperatures can cause the male gametophyte to abort, resulting in a decline in fruit set. By 2100 , the predicted rise in air temperature $\left(1.5-11^{\circ} \mathrm{C}\right)$ will have a significant impact on crop productivity [6]. As a result, agricultural plant reproductive behavior in these harsh settings must be thoroughly investigated [7].

Tomato fruit production is influenced by high-temperature stress, despite its capacity to thrive in a variety of climates, because increases in day/night temperatures above $26 / 20{ }^{\circ} \mathrm{C}$, respectively, can severely affect fruit setting and output [8]. With climate change, developing heat-tolerant cultivars that can withstand high temperatures and other abiotic pressures is a top goal. Commercial tomatoes, unlike Solanum chilense, have a limited heat tolerance capacity. Heat stress is the major hazard to agricultural output in many parts of the world because of global warming [9]. Increasing the daytime temperature above $25^{\circ} \mathrm{C}$ reduces the number of fruits, the weight of the fruit, and the number of seeds per fruit [10]. Short-term exposure to extremely high temperatures $\left(45^{\circ} \mathrm{C}\right)$ can cause programmed cell death (PCD), cytochrome c release, and the induction of caspase-like enzymes [11]. Plants in the reproductive stage are more vulnerable to high temperatures relative to the vegetative stage [12]. Due to elevated summer temperatures, tomato production is halted in numerous countries [13]. The lack of heat tolerance in most tomato cultivars makes it difficult to cultivate them in areas where temperatures exceed $38^{\circ} \mathrm{C}$ or more for part of the growing season, even if only for a short time [14]. High temperatures interfere with physiological and biochemical development, resulting in lower fruit yields [15]. Tomato plants are vulnerable to high temperatures that can stimulate the flower dropping [16] and reduce the fruit yield [17]. Temperature increases have a deleterious impact on the pollen grain, particularly during the initial stage, resulting in poor pollen germination and reduced pollen tube growth [18]. High temperatures not only diminish flowering and fruit set on the plant but also impair the development and maturity of the fruit, lowering crop production [19]. As a result, improving the heat tolerance of crops by molecular manipulation is critical. In plant cells, heat stress causes many heat-labile proteins to denature and increases damaging reactive oxygen species (ROS) [20].

When exposed to heat, heat-shock genes are quickly expressed, resulting in a rapid buildup of heat-shock proteins (HSPs). The heat shock transcription factors (HSFs) regulate HSP expression primarily at the transcriptional level, and they play an important role in high-temperature stress responses [21]. Plant HSF genes have been extracted from a variety of species since they were first discovered in tomatoes [22]. In an earlier study, there were many HSF genes identified in Arabidopsis (21) and rice (Oryza sativa L.) (25), respectively [23]. The HSF family, like many other TFs, has a modular structure with highly conserved domains [24]. The conserved structure includes the N-terminal DNAbinding domain (DBD) and the heptad hydrophobic repeats (HR-A/B) engaged with the nuclear localization signal (NLS) domain [23]. A C-terminal activation domain (CTAD) and a nuclear export signal (NES) domain are also found in several HSFs [25]. HSFs work by inducing a highly conserved heat shock element (HSE) in the promoters, which contains motifs in alternating orientations. Shim et al. [26] found that class A (HSFs) are engaged in transcriptional activation and environmental stress responses, whereas class B (HSFs) act as repressors of gene expression [27,28]. HSFB1 serves as a transcription co-activator with class A HSFs in Arabidopsis and as a repressor in tomatoes, according to previous studies [28]. Many species, including Arabidopsis, Chinese cabbage, rice, maize, Triticum aestivum, pepper, and grasses, have been extensively studied for the HSF gene family $[29,30]$. The current study was designed to explore the tomato genotypes collected from different hot climate regions of Saudi Arabia and to determine their response under field conditions and expression levels using different heat shock transcription factors (HSFs) of the SlyHSFs genes. 


\section{Results}

The descriptive statistics results suggested that there were a wide range of diversity present among the studied characters, i.e., plant height $(\mathrm{cm})$, thickness $(\mathrm{cm})$, fresh weight leaf (FWL), fresh weight stem (FWS), number of branches (NOB), fresh weight/plant (FW/p), dry weight leaf (DWL), dry weight stem (DWS), total dry weight/plant (TDW/plant), and leaf area/plant (LA/p) under three different temperature regimes (high temperature, medium temperature, and low temperature) at vegetative stage (Table 1). The mean data for all genotypes under three growing seasons are presented in Supplementary Table S1.

Table 1. Descriptive statistics of the studied characteristics of tomato genotypes during three growing seasons.

\begin{tabular}{lcccc}
\hline Traits & Mean & SD & Minimum & Maximum \\
\hline Plant height $(\mathrm{cm})$ & 66.86 & 6.7 & 52.90 & 83 \\
\hline DWL $(\mathrm{g})$ & 64.70 & 8.82 & 48 & 85.49 \\
\hline DWS $(\mathrm{g})$ & 45.17 & 6.22 & 34.26 & 60.53 \\
\hline FWL $(\mathrm{g})$ & 527.28 & 73.81 & 396.10 & 699 \\
\hline FW/p $(\mathrm{g})$ & 838.06 & 117.26 & 633.73 & 1114 \\
\hline FWS $(\mathrm{g})$ & 310.80 & 43.43 & 234.90 & 415 \\
\hline NoB & 6.96 & 0.86 & 5.6 & 8.90 \\
\hline LA/p $\left(\mathrm{cm}^{2}\right)$ & 5614.4 & 778.85 & 4248.3 & 7445.8
\end{tabular}

Plant height (PH), thickness (Th), fresh weight leaf (FWL), fresh weight stem (FWS), number of branches (NOB), fresh weight/plant (FW/p), dry weight leaf (DWL), dry weight stem (DWS), leaf area/plant (LA/p).

The study was conducted to determine the comparative expression profiling of the heat shock transcription factor (HSF) coding genes in the tomato cultivars. For that purpose, the tomato genotypes were exposed to different temperature regimes (high temp, medium temp, and low temp), and samples were collected for RNA extraction. The cDNA was synthesized for the comparative expression of the selected genotypes and actin was used as an internal control to normalize the reactions. For this purpose, 11 (HSF) genes were used to evaluate the expression (Table 2). As HSF genes participate in pathways associated with heat shock, a quantitative PCR analysis has been carried out in the tomato to comprehensively detect HSF gene expression functions. The relative expression was determined using the $\Delta \Delta \mathrm{Ct}$ among each primer used during the study. Furthermore, the genotype evaluation was performed by generating the graph on the CT mean value of each primer. Primer 1 (SlyHSF-01) results are presented in Figure 1.

Table 2. Genomic features of SlyHSF Genes in tomato.

\begin{tabular}{ccccccc}
\hline \multirow{2}{*}{ ID } & \multirow{2}{*}{ Name } & \multirow{2}{*}{ Start } & End & Gene (bp) & \# cDNA & $\begin{array}{c}\text { \# Amino } \\
\text { Acid }\end{array}$ \\
\hline SlyHSF-01 & Solyc11g064990.1 SL2.40ch11 & $47,389,718$ & $47,391,840$ & 2123 & 756 & 251 \\
\hline SlyHSF-02 & Solyc08g005170.2 SL2.40ch08 & 111,412 & 116,839 & 5428 & 1949 & 527 \\
\hline SlyHSF-03 & Solyc03g026020.2 SL2.40ch03 & $7,810,489$ & $7,812,280$ & 1792 & 1594 & 338 \\
\hline SlyHSF-04 & Solyc03g097120.2 SL2.40ch03 & $52,901,766$ & $52,904,929$ & 3164 & 1874 & 491 \\
\hline SlyHSF-05 & Solyc02g090820.2 SL2.40ch02 & $46,880,125$ & $46,883,382$ & 3258 & 1611 & 301 \\
\hline SlyHSF-06 & Solyc09g065660.2 SL2.40ch09 & $59,473,864$ & $59,475,995$ & 2132 & 1405 & 372 \\
\hline SlyHSF-07 & Solyc04g078770.2 SL2.40ch04 & $61,036,586$ & $61,037,903$ & 1318 & 1230 & 360 \\
\hline SlyHSF-08 & Solyc06g072750.2 SL2.40ch06 & $41,255,352$ & $41,258,348$ & 2997 & 1613 & 482 \\
\hline
\end{tabular}


Table 2. Cont.

\begin{tabular}{|c|c|c|c|c|c|c|}
\hline ID & Name & Start & End & Gene (bp) & \# cDNA & $\begin{array}{c}\text { \# Amino } \\
\text { Acid }\end{array}$ \\
\hline SlyHSF-09 & Solyc12g098520.1 SL2.40ch12 & $48,549,454$ & $48,552,229$ & 2776 & 1437 & 478 \\
\hline SlyHSF-10 & Solyc08g080540.2 SL2.40ch08 & $60,985,869$ & $60,987,278$ & 1410 & 1329 & 325 \\
\hline SlyHSF-11 & Solyc04g016000.2 SL2.40ch04 & $6,594,909$ & $6,598,451$ & 3543 & 1320 & 237 \\
\hline
\end{tabular}

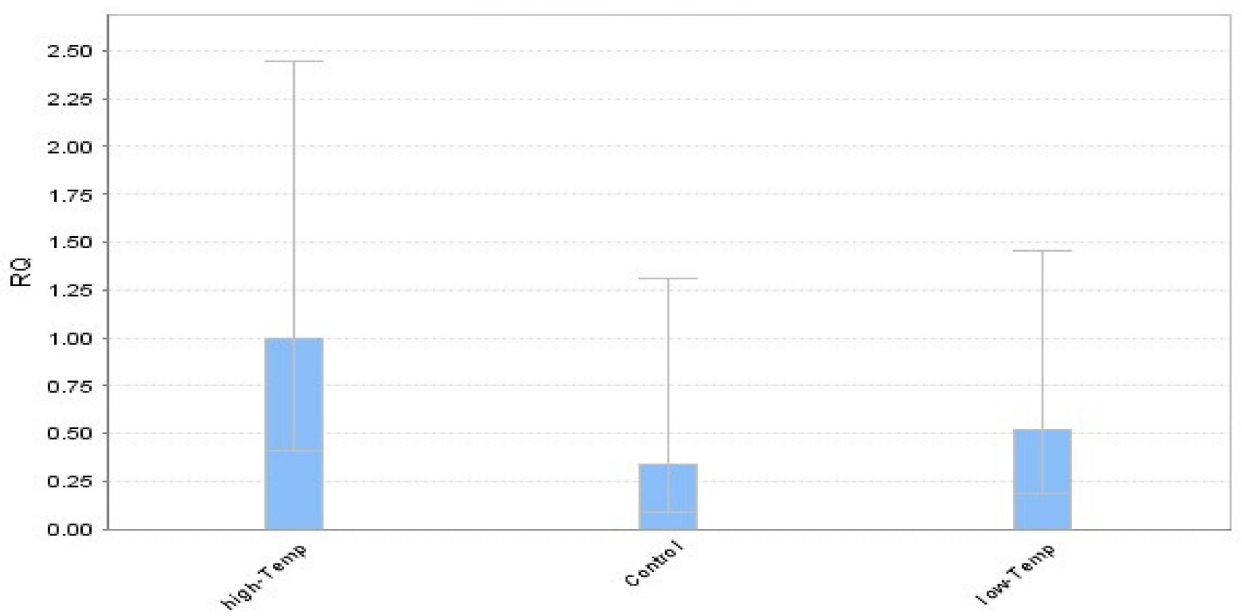

Figure 1. Relative quantification (RQ) of the heat shock transcription factor (SlyHSF-01) gene under different temperature regimes in tomato genotypes. (High temperature $=42{ }^{\circ} \mathrm{C}$, low temperature $=12^{\circ} \mathrm{C}$, medium temperature $=25^{\circ} \mathrm{C}$ ). Beta-actin gene was used as an internal control for quantitative expression.

From the figure, it was predicted that all the genotypes recorded upregulation of the heat shock transcription factors (HSFs) at high temperatures as compared to medium and low temperatures (Figure 1). Furthermore, the expression was also recorded more at lowtemperature collections of the samples as compared to the control (medium temperature).

The expression of the SlyHSF-02 genes for all tomato genotypes was presented in Figure 2. The results were quite opposite as compared to the SlyHSF-01 recorded downregulation of the HSF function; however, some genotypes (Al-Qatif-365, Al-Ahsa-308, Marmande Vf, and Pearsons improved) recorded upregulation under high temperature. The maximum expression was recorded under lower-temperature treatment, while the minimum was under high temperature relative to the control (Figure 2). While at the same time, SlyHSF-03 also recorded maximum expression in high-temperature treatment relative to control and low temperature (Figure 2). The SlyHSF-04 and SlyHSF-05 expression results are presented in Figure 3. The maximum expression was recorded under control (medium temp) regimes as compared to other temperature treatments. At high-temperature treatments, the HSP genes were down-regulated in both cases (SlyHSF-04; SlyHSF-05). The comparative expressions of the SlyHSF-08 and SlyHSF-09 are presented in Figure 4. The HSF genes were upregulated in the SlyHSF-08 as well as SlyHSF-09 primers relative to other temperature treatments. 

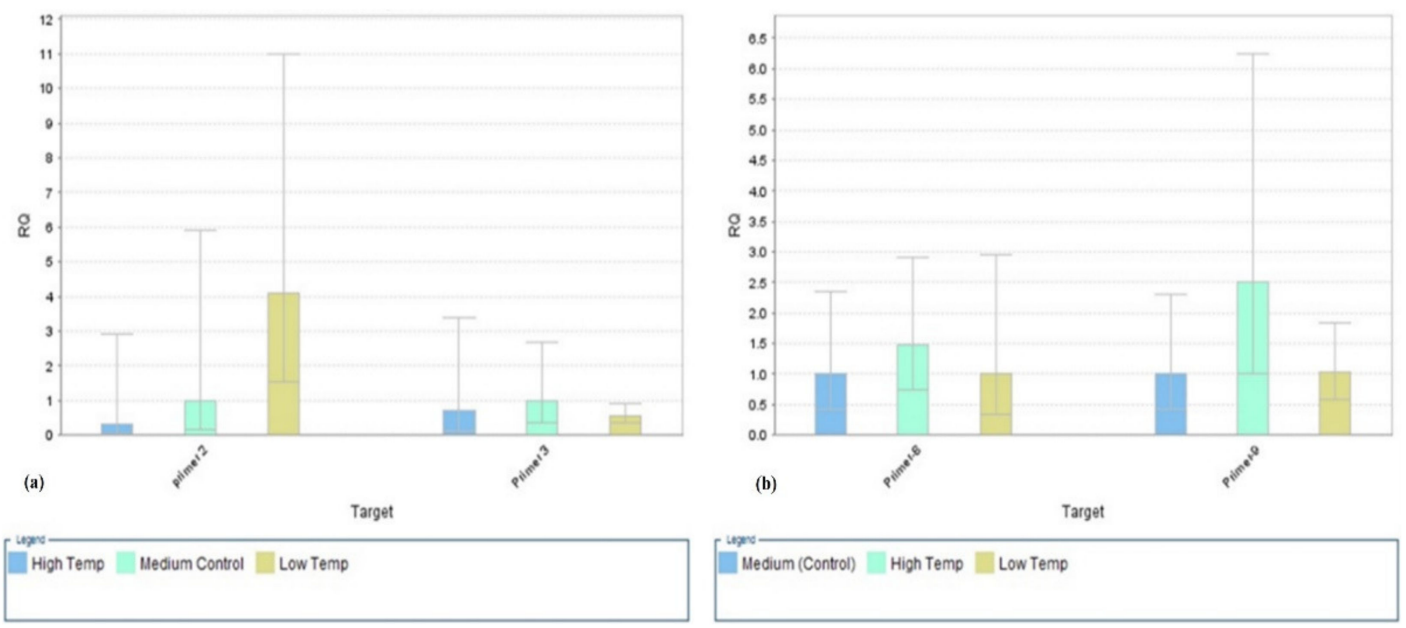

Figure 2. Relative quantification (RQ) of the heat shock transcription factor (SlyHSF-02 and 3, (a)) (SlyHSF-08 and 09, (b)) genes under different temperature regimes. (High temperature $=42{ }^{\circ} \mathrm{C}$, low temperature $=12{ }^{\circ} \mathrm{C}$, medium temperature $=25^{\circ} \mathrm{C}$ ). Beta-actin gene was used as an internal control for quantitative expression.
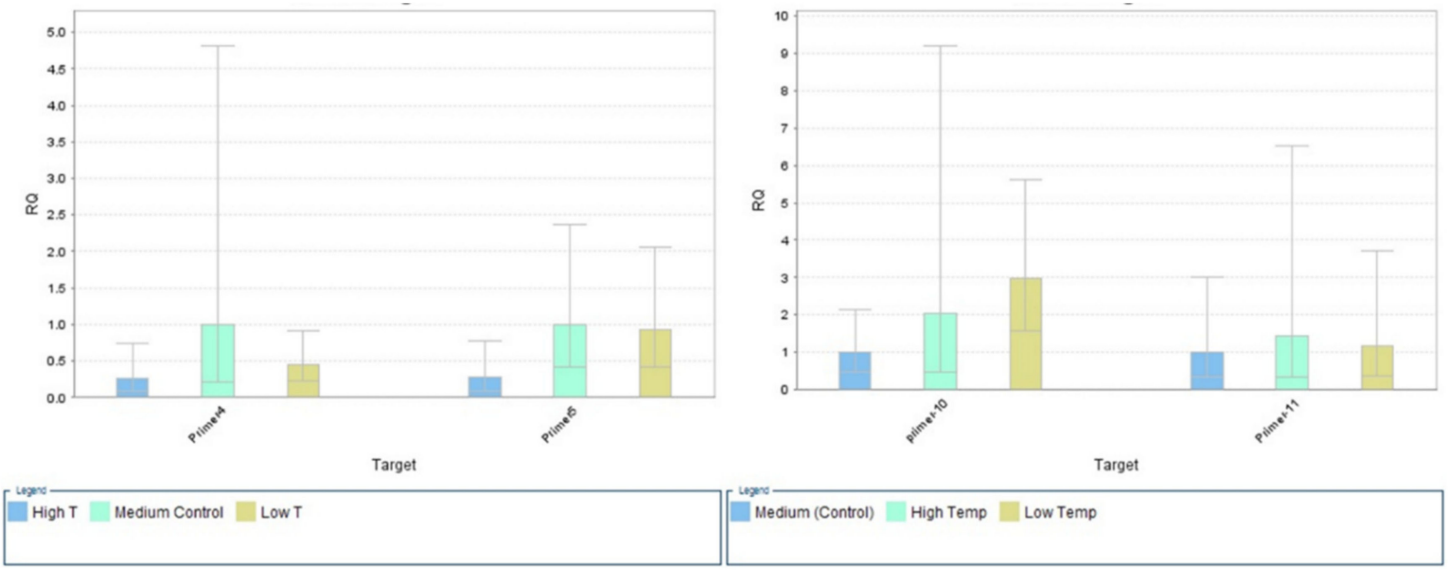

Figure 3. Relative expression of heat shock transcription factor genes under different temperature regimes left, SlyHSF-04 and 5; right, SlyHSF-10 \& 11 (high temperature $=42{ }^{\circ} \mathrm{C}$, low temperature $=12{ }^{\circ} \mathrm{C}$, medium temperature $=25^{\circ} \mathrm{C}$ ). Beta-actin gene was used as internal control for quantitative expression.

The comparative expression of result for the primers, SlyHSF-10 and SlyHSF-11, are presented in Figure 3. SlyHSF-10 recorded upregulation of HSF and was significant as compared to other treatments. Similarly, the comparative expression of the SlyHSF-11 also recorded upregulation of HSF genes while downregulation was recorded under control treatment (Figure 3).

The fold expression of each tomato genotype was also determined under the high temperature relative to the control (medium temperature). The gene (SlyHSFs-01) recorded significant fold change expression relative to the control (Figure 4a). The maximum expression was recorded in Super Strain B (7.0) followed by Valentine (6.5) under high-temperature stress relative to the control. Similarly, SlyHSFs-2 also recorded significant upregulation under high-stress temperature in Marmande VF (8.38) and Al-Qatif-365 (Figure 4b). The upregulation was also recorded as significant in Pearson Early, but relative to the control, it was downregulated under high-temperature stress conditions. Similarly, Al-Qatif-365 recorded the highest expression when SlyHSFs-8 (Figure 4c) and SlyHSFs-9 (Figure 4d) genes were used, respectively, followed by strain B and Marmande VF tomato genotypes 
under high-temperature stress conditions. The heat map of the heat shock transcription factors (HSFs) shows that the expression-based hierarchical clustering of genes confirms the upregulation and downregulation of heat shock factor genes among the tomato genotypes (Figure 5).
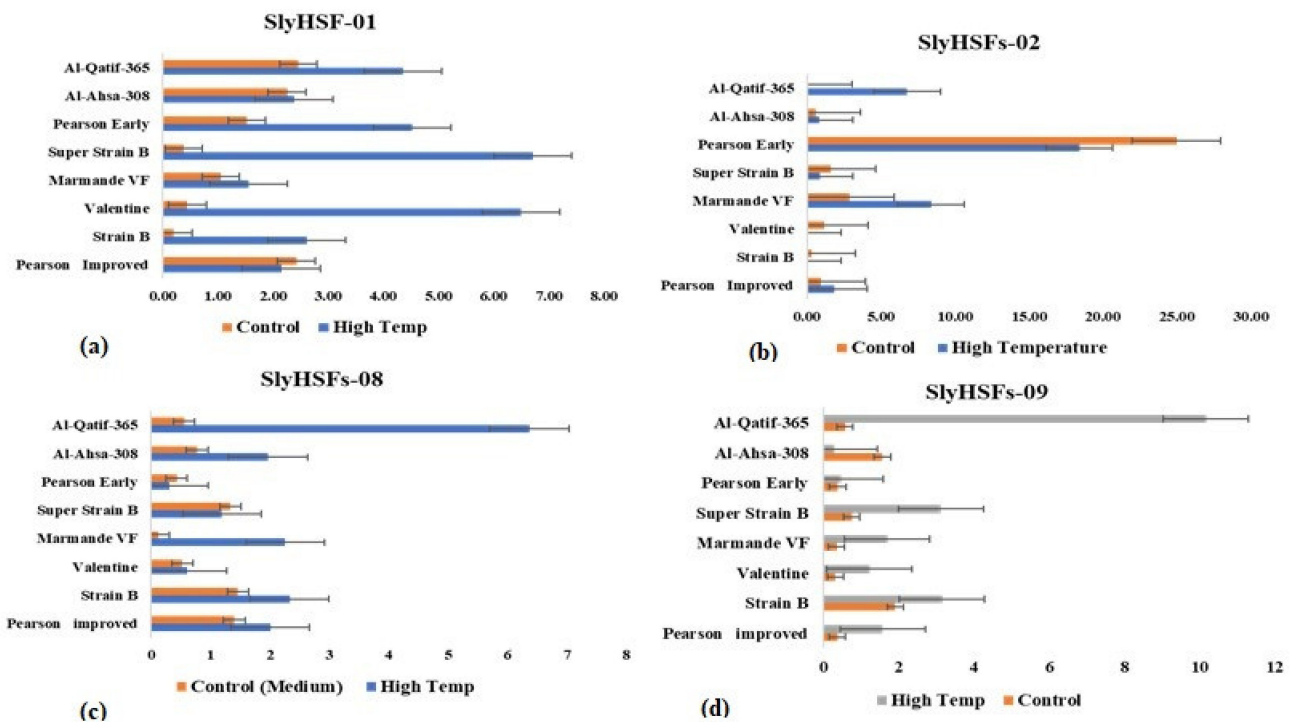

Figure 4. Fold change expression difference of individual tomato genotypes using different heat shock transcription factors genes ((a) SlyHSF-1, (b) SlyHSF-2, (c) SlyHSFs-8, (d) SlyHSFs-9).

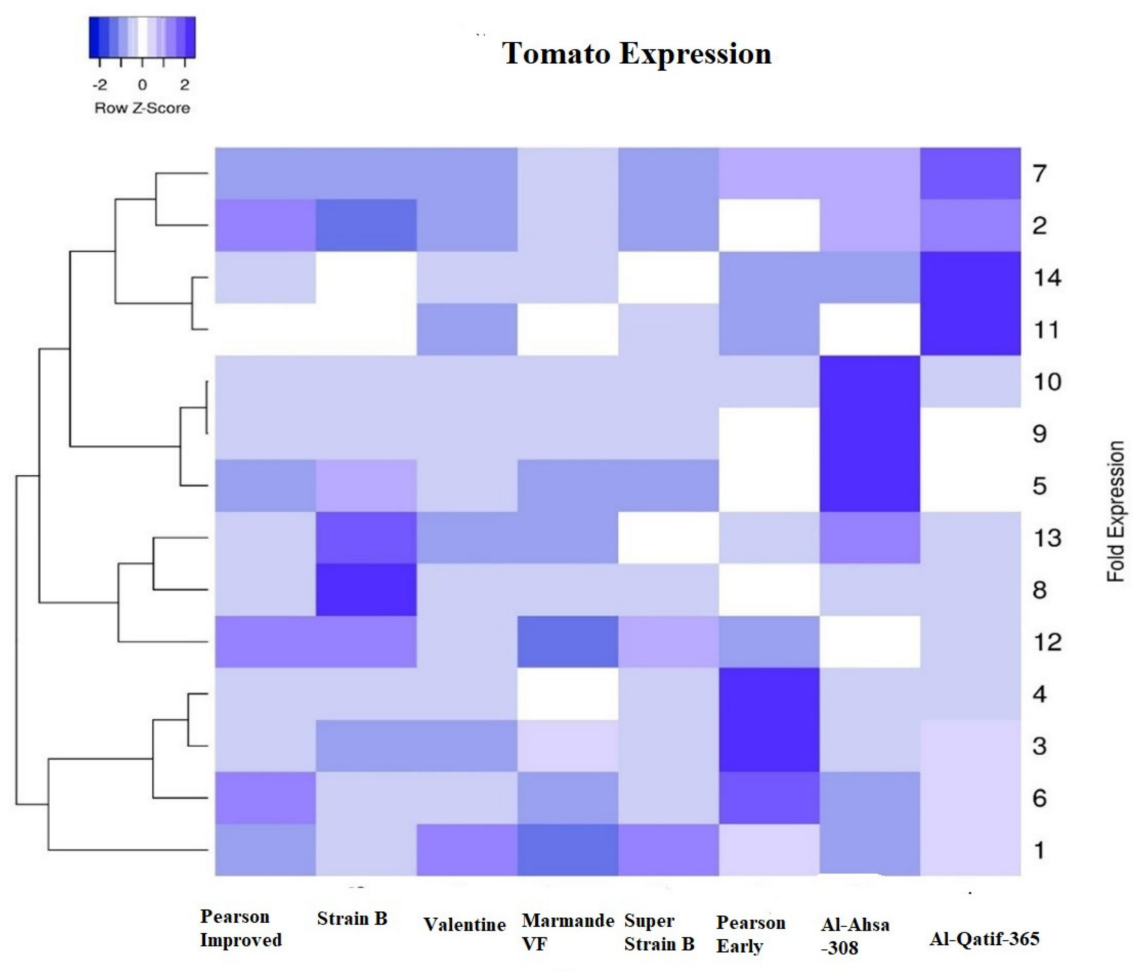

\section{Genotypes}

Figure 5. Heat map of heat shock transcription factor (HSF) samples collected at high-temperature stress and medium stress in tomato genotypes. The expression-based hierarchical clustering of genes is presented to show various gene clusters. The color intensity represents the degree of change in each tomato genotype; dark blue represents upregulation, and light blue represents downregulation. 


\section{Discussion}

Characterizing heat stress tolerance genotypes is significant to figuring out the target genotypes' responses under different temperature regimes. The current study was designed to determine the heat-resistant genotypes based on phenotypic data as well as gene expression data under different temperature regimes. The combination of temperatures, relative humidity, and solar radiation defined the growing conditions. In heat stress research, temperatures are frequently given more weightage than relative humidity [31]. High relative humidity (over $70 \%$ ) can, on the other hand, exacerbate the effects of high temperatures on crops [32]. When testing for heat stress tolerance in tomatoes, more attention should be paid to both temperature and relative humidity [33]. The results suggested that the vegetative characters recorded a significant effect from heat stress, and it was also found that there were significant differences present between the genotypes and different temperature regimes. The plant height $(\mathrm{cm})$, thickness $(\mathrm{cm})$, fresh weight leaf $(\mathrm{FWL})$, fresh weight stem (FWS), number of branches (NOB), fresh weight/plant (FW/p), dry weight leaf (DWL), dry weight stem (DWS), total dry weight/plant (TDW/plant), and leaf area/plant (LA/p) were recorded in the Valentine genotype, followed by the Pearson improved genotype; however, the minimum was recorded in the Al-Qatif tomato genotype. Similar results were reported by Ayenan et al. [33], suggesting that different heat stress periods affect the vegetative and yield components in tomato cultivars.

The heat shock transcription factor was found 30 years ago and takes part in the genes under thermal stress, which can produce thermal shock protein, i.e., it exhibits a high degree of gene expression during thermal stress with a transcriptive activation. When a plant is exposed to thermal stress, however, the expression of heat-shock genes rises, resulting in a rapid accumulation of heat-shock proteins (HSPs). When it was originally identified from tomatoes, the understanding of heat transcription factors had just begun [34]. It has demonstrated a remarkable effect in assisting plants, particularly Solanaceous, in withstanding heat stress that is approximately $5-10{ }^{\circ} \mathrm{C}$ over the plant's usual growing temperature. Given that global warming is increasing marginal land and posing a threat to the production of vital food and cash crops, such as solanaceous, it is critical to investigate heat shock transcription factors that can help plants endure heat stress to the greatest extent possible. When a plant is exposed to high temperatures (thermal stress), the heat transcription factor, also known as the central regulator of the heat shock stress response, regulates the expression of many heat-stress-inducible genes at the transcriptional level by recognizing conserved binding motifs (heat stress element, HSE) found in the promoter region, allowing the plant to withstand the stress. HSPs also protect cells from heat and other environmental challenges while also contributing to protein folding, which aids protein function, cell differentiation, dimensional structure, and conformation [35]. The tomato (Lycopersicon esculentum) is induced by heat shock proteins (HSPs) of the leaf induced by the heat treatment and under normal growth conditions of the fruits during the chloroplast transition into chromoplasts [36]. The synthetics of a set of evolutionary polypeptides called heat shock proteins (HSPs) are the response of every organism to high temperatures. Small HSPs ( $S H S P s$ ) have a conserved sequence at their $\mathrm{C}$ terminus and are connected to other organisms' HSPs and the crystallins of the vertebrate eye lens. They range in size from 15 to $42 \mathrm{KD}$ [37]. The most abundant and diversified category of proteins generated in response to heat stress is plant sHSPs. Other environmental conditions, such as cold, drought, or salinity, can also cause these proteins to be produced, as well as during developmental processes, including embryogenesis, germination, and fruit development [38]. Based on sequence alignments, immunological cross-reactivity, and cellular compartmentalization, sHSPs have been divided into six classes. The cytoplasm or nucleus was found in three classes (CI, CII, and CIII). The endoplasmic reticulum, mitochondria, and chloroplast were in other classes. The links between HSP synthesis and the stress response led to the belief that these proteins protect cells from the associated high-temperature-damaging consequences [37]. While it has been demonstrated that both plant and human HSPs do not have an ATP-dependent chaperone function in vitro, the 
mechanism by which sHSPs are engaged in cell protection is not entirely understood [39]. sHSPs acts as chaperones by preventing irreversible aggregation of heat stress denatured proteins in an independent way. As HSF genes participate in pathways associated with heat shock, a quantitative PCR analysis has been carried out in using real-time PCR in the tomato for a comprehensive study to detect HSF gene expression. The non-conserved regions have been utilized for the first design to ensure the PCR amplification specificity (Table 1). The expression of most SlyHSF genes was drastically enhanced with heat stress treatment. After the treatment of heat stress in all samples, the genes, SlyHSF-01, $-8,-9,-10$, and -11 , have been expressed more under high-temperature conditions while genes SlyHSF-04, and -5 were expressed more under medium or moderate temperature. However, the gene SlyHSF02 was expressed more under low-temperature treatment. SlyHSF-01 and -02 in tomatoes have been demonstrated to be master regulators for activating heat response and can lead to developing thermotolerance [40]. Similar results were also recorded by Mishra et al., (2002), suggesting that the HSFA1a (SlyHSF-02) gene represents as the heat response is triggered by a master regulator, which might lead to the development of thermotolerance; however, HSFA1a regulation was not shown to be important in another study [40]. Because HSF genes have been linked to heat shock pathways, quantitative real-time PCR analysis was used to systematically detect HSF gene expression in tomatoes. To ensure the specificity of PCR amplification, non-conserved areas were chosen for the primer design. Moreover, Yang et al. [40] also suggested that different SlySHFs genes, such as [02-04-06-16-17-18], had more than ten interaction linkages discovered. However, the SlyHSF genes [07-10-12] found that interactions between tomato HSF genes existed. A dynamic protein structure was present in small heat shock protein (sHSPs) having diverse evolutionary origins. The structure is widely used in human diseases, as well as in plants stress acclimatization and other organisms. For that purpose, the ethylene-induced transient structure was used to suppress the HSP genes regulated by the RIN protein, representing their basic role in plant biology, especially in fruit ripening [41,42]. Similar transient suppression results were suggested when the Rd22 gene expression in ABA-attuned plants represents stress tolerance [43]. Another study was conducted to determine the expression and interaction of heat shock proteins in tomato plants in protoplast cells, both with and without heat shock transcription factor A2 (HsfA2) under two different heat stress conditions. The findings show that depending on whether HsfA2, a critical regulator of HSPs, is activated or repressed, distinct sHSPs are upregulated. Furthermore, studies of protein-protein interactions between the sHSP protein family and other heat shock response proteins (HSP70, HSP90, and MBF1c) reveal that numerous sHSPs are mediating alternate stress responses via a regulatory subnetwork independent of HsfA2 [44]. Similarly, HSBP1 was introduced in tomato crops using the TILLING technique to determine the effects of mutation HSBP1 protein functionally at protoplast level and to compare thermotolerance capacity in wild-type tomato genotypes. The results suggested that due to the mutation, the methionine-to-isoleucine mutation partial protein function was lost; as a result, the Hsf inhibitory effect was lost. On the other hand, mutant plants showed thermotolerance; however, matured plants recorded tolerance in HS treatments. Adversely, the wild-type (homozygous) plants or mutant plants recorded no significant differences under the control condition. Cumulatively, the results suggested that identified mutants with HSBP1 can be used as a genetic tool in breeding programs for thermotolerance activity in tomato crops [45]. Under physiological settings, maize EMP2/HSBP1 acts in the early stages of kernel formation, indicating that it has a developmental role [46]. HSBP interacts solely with class A HSFs, and individual HSBPs have distinct specificities for different HsfA members. HsfA2e, HsfA3, HsfA4d, and HsfA5 interact with maize EMP1/HSBP1, whereas HsfA2c and HsfA4a bind to HSBP2 [47]. Transgenic lines reveal changes in the transcript regulation of HSF-dependent genes, such as HSPs, which is consistent with a differential interaction profile that pairs OsHSBP1 and OsHSBP2 with different HSFs [48]. Tomatoes are an essential crop for both economic and gastronomic reasons all over the world, and they've long been used as a model plant for flesh fruit development [49]. Several HSFs, including HsfA2, 
were expressed in tomato anthers during the early stages of pollen production, suggesting that SIHSBP1 may play a regulatory function in HSF development [50-52]. These findings are consistent with prior research that has revealed that HSBP1 has a repressor role [53].

\section{Materials and Methods}

\subsection{Plant Materials}

The tomato genotypes used for this study (Table 1) comprised six commercially available cultivars in the local market (Pearson Improved, Strain B, Valentine, Marmande VF, Super Strain B, and Pearson Early) and two local Saudi cultivars (Al-Ahsa and Al-Qatif) from the Plant Gene Bank of the Ministry of Environment, Water and Agriculture (MEWA) in Riyadh, Saudi Arabia. Four-week-old seedlings were transplanted on beds of $100 \mathrm{~cm}$ between rows and $50 \mathrm{~cm}$ between plants. They were transplanted on three different periods during the 2019 season: period 1 ( 2 August), period 2 (3 September), and period 3 (1 October). Experiments were conducted at the Research Farm of the Plant Production Department, College of Food and Agriculture Sciences, King Saud University, Riyadh, Saudi Arabia. The soil of the experimental field is characterized as sandy loam with the physicochemical properties summarized in Table 3.

Table 3. Physical characteristics of soil.

\begin{tabular}{|c|c|c|c|c|c|c|c|c|c|c|c|c|}
\hline \multicolumn{4}{|c|}{ Soil Texture } & \multirow{2}{*}{$\mathrm{pH}$} & \multirow{2}{*}{$\begin{array}{c}\text { EC dS } \\
m^{-1}\end{array}$} & \multicolumn{4}{|c|}{ Anions $\left(m E q L^{-1}\right)$} & \multicolumn{3}{|c|}{ Cations $\left(\mathrm{mEq} \mathrm{L} \mathrm{L}^{-1}\right)$} \\
\hline $\begin{array}{c}\text { Clay } \\
(\%)\end{array}$ & $\begin{array}{l}\text { Silt } \\
(\%)\end{array}$ & $\begin{array}{c}\text { Sand } \\
(\%)\end{array}$ & $\begin{array}{l}\text { Soil } \\
\text { Type }\end{array}$ & & & $\mathrm{Ca}$ & $\mathrm{Mg}$ & $\mathbf{K}$ & $\mathrm{Na}$ & $\mathrm{HCO}_{3}$ & $\mathrm{Cl}$ & $\mathrm{SO}_{4}$ \\
\hline 8.45 & 7.83 & 83.72 & $\begin{array}{l}\text { Sandy } \\
\text { Loam }\end{array}$ & 7.8 & 1.98 & 10.50 & 4.50 & 1.32 & 6.97 & 2.30 & 2.65 & 18.34 \\
\hline
\end{tabular}

Temperatures were recorded from the on-site weather station. In general, the maximum and minimum mean daily temperatures were $42{ }^{\circ} \mathrm{C}$ (summer) and $12{ }^{\circ} \mathrm{C}$ (winter), respectively [54]. Growing degree day $(G D D)$ equations can transfer climate data into useful agricultural applications that growers can use to make strategic decisions [55]. GDDs were calculated during the tomato growing season using the GDD model in Equation (1) [56]. The cumulative growing degree days (CGDDs), however, were calculated by taking the sum of the GDDs as in Equation (2).

$$
G D D=\frac{T_{\max }+T_{\min }}{2}-T_{\text {base }}
$$

where $T_{\max }$ and $T_{\min }$ are the maximum and minimum daily temperatures $\left({ }^{\circ} \mathrm{C}\right)$, and $T_{\text {base }}$ is the base temperature $\left(10{ }^{\circ} \mathrm{C}\right.$ for tomato $)$.

$$
C G D D=\sum_{j=1}^{n} G D D_{j}
$$

where $j$ is the indicated day, $n$ is a specific day during the growth period, and GDD $j$ is the heating unit on a $j$ th day $\left({ }^{\circ} \mathrm{Cd}\right)$.

The seeds of the genotypes were sown in JV7 pellets (Jiffy Products, Stange, Norway) under greenhouse environmental conditions at three seeding periods to obtain four weeks of vigorous transplants ready to be transplanted in the field at three scheduled planting dates: 1 August 2019, 1 September 2019, and 1 October 2019. Planting distance was $40 \mathrm{~cm}$ between plants and $100 \mathrm{~cm}$ between lines (Figure 4). The selection of the planting dates was based on the fact that tomato plants will be exposed to different day/night regimes and therefore, different levels of heat stress during flowering and fruit set. The average temperature, relative humidity, and solar radiation during each growing period are shown in Supplementary Table S1. Climatic data were collected during the agricultural growing seasons implemented in this study, using one of the meteorological stations located within 
the scope of the study implementation site (Western Nakhil-IRIYADH23). The following were the time frames for each of the planting dates: first planting date (low temperature), 1 August 2019-10 November 2019 (102 days), second planting date (medium temperature), 1 September 2019-25 December 2019 (116 days), and third planting date (high temperature), 1 October 2019-15 February 2019 (138 days).

The maximum and minimum temperatures and the average daily temperature, humidity, and solar radiation were collected during the period from the beginning of July 2019 to the end of February 2020, and then the average weekly temperature was calculated for each month separately. The study used a split-plot in a randomized complete block design with three replications. Season growing treatments were assigned at random to the main plots, while genotypes were assigned to the sub-plots. Three plants from each subplot were randomly selected for the measurements of the vegetative traits in the tomato crop under different temperature regimes.

\subsection{Measurement of Growth Parameters}

The plant's main stem height was measured from the beginning of the adventitious roots to the top of the plant. The leaf area was measured using the Portable Area Meter (Model LI-3000A, LI-COR, USA). The leaves of the plant were collected and weighed, and then a sample (100 g) was taken and dried at $70{ }^{\circ} \mathrm{C}$ in a forced air-oven until the weight became constant (48-72 h), and the dry matter contents were calculated relative to the total fresh weight of the leaves of the plant. The stem of the plant was collected and weighed, and then a sample (100 g) was taken from them and dried at $70{ }^{\circ} \mathrm{C}$ in a forced air-oven until the weight became constant (48-72 h), and the dry matter contents were calculated relative to the total fresh weight of the stem of the plant.

\subsection{Total RNA Extraction}

Leaf tissues from the control $\left(30^{\circ} \mathrm{C}\right)$, medium temperature $\left(40^{\circ} \mathrm{C}\right)$, and high temperature $\left(45^{\circ} \mathrm{C}\right)$ plants were collected, immersed in liquid nitrogen, and stored at $-80{ }^{\circ} \mathrm{C}$ until the RNA was extracted. Using a total RNA extraction kit (SV total RNA isolation system, Promega, Madison, IL, USA), the total RNA was isolated from $100 \mathrm{mg}$ of the control, medium temperature, and high-temperature leaves according to the manufacturer's recommended technique. Using a mortar and pestle, $100 \mathrm{mg}$ of plant tissue was thoroughly mashed in liquid nitrogen. Tissue powder was transferred to a $2 \mathrm{~mL}$ liquid $\mathrm{N}_{2}$ cooled microcentrifuge tube that was devoid of RNase. It was then incubated at room temperature for 3 min after adding $450 \mu \mathrm{L}$ RNA lysis buffer to tissue powder and $350 \mu \mathrm{L}$ dilution buffer to the lysate. The sample was centrifuged for $10 \mathrm{~min}$ at 12,000 rpm following incubation. The clear lysate was then pipetted to a fresh centrifuge tube, $200 \mu \mathrm{L}$ of 95 percent ethanol was added to clear lysate, and $200 \mu \mathrm{L}$ of 95 percent ethanol was added to clear lysate and pipetted three to four times. After that, the mixture was transported to a spin column assembly and centrifuged at 12,000 rpm for $2 \mathrm{~min}$. After carefully discarding the flow, $600 \mu \mathrm{L}$ of RNA washing buffer was added to the spin column, and the membrane was washed by centrifugation for $2 \mathrm{~min}$ at 12,000 pm. The flow-through was discarded, and $250 \mu \mathrm{L}$ of RNA washing buffer was added to wash the RNA before centrifugation at 12,000 rpm for $2 \mathrm{~min}$. The flow-through was discarded, and the samples were treated for $15 \mathrm{~min}$ at room temperature with DNase incubation $(3 \mu \mathrm{L})$ buffer and DNase stop solution. After that, two RNA wash buffer washes were performed ( $600 \mu \mathrm{L}$ RNA washing buffer and centrifuged for $2 \mathrm{~min}$ ). To elute the RNA, $100 \mu \mathrm{L}$ of RNase-free water was added directly to the middle of the spin column membrane and centrifuged for $1 \mathrm{~min}$ at $12,000 \mathrm{rpm}$. The total RNA quantity was quantified using a Nanodrop 2000 spectrophotometer (Thermo Scientific, Waltham, MA, USA), and the integrity of the RNA was evaluated using a 1.2 percent denaturing formaldehyde agarose gel. RNA was then kept at $-80^{\circ} \mathrm{C}$ for future use. 


\section{4. cDNA Synthesis}

cDNA was synthesized using a superscript III first-strand kit (Thermo Fisher Scientific, Waltham, MA, USA) according to the manufacturer's instructions. Random hexamer primers and deoxyribonucleotide 5-triphosphate (dNTPs) were added to $5 \mu \mathrm{g}$ total RNA and the mixture was incubated at $65^{\circ} \mathrm{C}$ for $5 \mathrm{~min}$ before chilling on ice. The first strand was then reverse transcribed by adding the first strand buffer, $20 \mathrm{mM}$ dithiothreitol, and superscript III reverse transcriptase to a final volume of $20 \mu \mathrm{L}$ and then incubating the mixture at $42{ }^{\circ} \mathrm{C}$ for $1 \mathrm{~h}$. The cDNA obtained was diluted 1:20 $(v / v)$ with deionized water and stored at $-20^{\circ} \mathrm{C}$.

\subsection{Potential Candidate Genes for Heat Shock Protein in Tomato}

The following genes were selected from the literature of Yang et al. [40] from the tomato genome database. The characteristics of the selected genes are presented in Table 1.

\subsection{Quantitative Real-Time PCR}

All selected primers were validated on 10 genotypes based on condition-specific (cold, medium, and heat) stress samples. All the reactions were performed in triplicate on the ABI machine 7500. Actin genes were selected as reference genes due to their consistent expression. Each reaction consisted of $1 \mu \mathrm{L}$ of cDNA, $10 \mu \mathrm{L}$ of SYBR green PCR master mix, $0.5 \mu \mathrm{L}$ each of forward and reversed primers, and water up to $20 \mu \mathrm{L}$. The thermocycling protocol consisted of $50{ }^{\circ} \mathrm{C}$ for 2 mins, initial denaturation at $95{ }^{\circ} \mathrm{C}$ for $10 \mathrm{~min}, 40$ cycles each of denaturation at $95^{\circ} \mathrm{C}$ for $0.15 \mathrm{~min}$, and annealing/extension at $56{ }^{\circ} \mathrm{C}$ for $30 \mathrm{~s}$. A melting curve analysis protocol was performed to confirm the absence of multiple amplicons and primer dimers. Negative control was also included to ensure the absence of contamination. In addition, the presence of genomic DNA contamination was checked by performing reactions without reverse transcriptase. The PCR efficiency was determined using a standard curve based on five to seven different four-fold dilutions of cDNA cloned amplicon.

\subsection{Data Analysis}

The data were statistically analyzed using the XL-STAT statistical package software (Ver. 2019, Excel Add-ins soft SARL, New York, NY, USA). The cycle's threshold values were calculated by the software, and data were exported to MS Excel for further analysis. Comparative $\mathrm{Ct}$ methods were used to estimate the expression differences. The $\mathrm{Ct}$ values of control and stressed samples were normalized with internal standards using the following formula. $\Delta \Delta \mathrm{Ct}=\Delta \mathrm{C} \mathrm{t}^{\mathrm{target}}\left(\mathrm{m}^{\mathrm{Cttarget}}-\mathrm{m}^{\text {Ctendogenous control }}\right)-\Delta \mathrm{Ct}$ control $\left(\mathrm{m}^{\text {Ctcontrol }}-\mathrm{m}^{\text {Ctendogenous control }}\right.$ ). The fold difference will be determined using power 2$\Delta \Delta \mathrm{Ct}$. The gene expression data were used to construct the heat map expression (http: / / www.heatmapper.ca/expression/, accessed on 5 November 2021) profiles [57]; their differential expression was shown in high-temperature stress conditions to validate the study.

\section{Conclusions}

The descriptive statistics results suggested that there was a wide range of differences recorded under three different growing seasons. The qPCR study revealed the expression patterns of HSF genes in tomatoes that followed treatment in high temperate temperatures. Four genes, SlyHSFs-1, SlyHSFs-2, SlyHSFs-8, and SlyHSFs-9 recorded upregulation expression relative to SlyHSFs-3, SlyHSFs-5, SlyHSFs-10, and SlyHSFs-11. The genotypes Strain B, Marmande VF, Pearson's Early, and the Landrace Al-Qatif-365 recorded the tolerant tomato genotypes under high-temperature stress. These genotypes will be introduced into a breeding program to improve tomato responses to heat stress.

Supplementary Materials: The following are available online at https:/ / www.mdpi.com/article/ 10.3390/plants11050615/s1, Table S1: Mean data for all genotypes under three growing seasons. 


\begin{abstract}
Author Contributions: Conceptualization, A.A.A. (Abdulhakim A. Aldubai) and A.A.A. (Abdullah A. Alsadon); methodology, M.A. and S.S.A.; software, M.A. and S.A.A.-F.; validation, A.A.A. (Abdulhakim A. Aldubai) and M.A.; investigation, A.A.A. (Abdulhakim A. Aldubai); resources, A.A.A. (Abdullah A. Alsadon); data curation, M.A.; writing-original draft preparation, A.A.A. (Abdulhakim A. Aldubai), A.A.A. (Abdullah A. Alsadon), H.H.M. and M.A.; writing-review and editing, A.A.A. (Abdullah A. Alsadon), H.H.M., A.A.A. (Abdulhakim A. Aldubai) and M.A. All authors have read and agreed to the published version of the manuscript.
\end{abstract}

Funding: This research was funded by the Deanship of Scientific Research in King Saud University, the initiative of the DSR Graduate Students Research Support (GSR).

Institutional Review Board Statement: Not applicable.

Informed Consent Statement: Not applicable.

Data Availability Statement: All the data supporting this article were included in the main text.

Conflicts of Interest: The authors declare no conflict of interest.

\title{
References
}

1. Wu, F.; Tanksley, S.D. Chromosomal evolution in the plant family Solanaceae. BMC Genom. 2010, 11, 182. [CrossRef]

2. Choudhary, A.K.; Thakur, S.; Suri, V. Technology transfer model on integrated nutrient management technology for sustainable crop production in high-value cash crops and vegetables in northwestern Himalayas. Commun. Soil Sci. Plant Anal. 2013, 44, 1684-1699. [CrossRef]

3. Food and Agriculture Organization of the United Nations (FAO). FAOSTAT Database. 2016. Available online: http:/ / faostat.fao. org/site/291/default.aspx (accessed on 12 October 2021).

4. Wahid, A.; Gelani, S.; Ashraf, M.; Foolad, M.R. Heat tolerance in plants: An overview. Environ. Exp. Bot. 2007, 61, 199-223. [CrossRef]

5. Blum, A. Plant Breeding for Stress Environments; CRC Press: Boca Raton, FL, USA, 1988.

6. Reddy, K.R.; Kakani, V. Screening Capsicum species of different origins for high temperature tolerance by in vitro pollen germination and pollen tube length. Sci. Hortic. 2007, 112, 130-135. [CrossRef]

7. Karapanos, I.; Akoumianakis, K.; Olympios, C.; Passam, H.C. Tomato pollen respiration in relation to in vitro germination and pollen tube growth under favourable and stress-inducing temperatures. Sex. Plant Reprod. 2010, 23, 219-224. [CrossRef] [PubMed]

8. Lohar, D.; Peat, W. Floral characteristics of heat-tolerant and heat-sensitive tomato (Lycopersicon esculentum Mill.) cultivars at high temperature. Sci. Hortic. 1998, 73, 53-60. [CrossRef]

9. Hedhly, A.; Hormaza, J.; Herrero, M. Flower emasculation accelerates ovule degeneration and reduces fruit set in sweet cherry. Sci. Hortic. 2009, 119, 455-457. [CrossRef]

10. Peet, M.; Sato, S.; Gardner, R. Comparing heat stress effects on male-fertile and male-sterile tomatoes. Plant Cell Environ. 1998, 21, 225-231. [CrossRef]

11. Qu, G.-Q.; Liu, X.; Zhang, Y.-L.; Yao, D.; Ma, Q.-M.; Yang, M.-Y.; Zhu, W.-H.; Yu, S.; Luo, Y.-B. Evidence for programmed cell death and activation of specific caspase-like enzymes in the tomato fruit heat stress response. Planta 2009, 229, 1269-1279. [CrossRef] [PubMed]

12. Zinn, K.E.; Tunc-Ozdemir, M.; Harper, J.F. Temperature stress and plant sexual reproduction: Uncovering the weakest links. J. Exp. Bot. 2010, 61, 1959-1968. [CrossRef] [PubMed]

13. Saeed, A.; Hayat, K.; Khan, A.; Iqbal, S. Heat tolerance studies in tomato (Lycopersicon esculentum Mill.). Int. J. Agric. Biol. 2007, 9 , 649-652.

14. Sung, S.S.; Brassington, A.-M.E.; Krakowiak, P.A.; Carey, J.C.; Jorde, L.B.; Bamshad, M. Mutations in TNNT3 cause multiple congenital contractures: A second locus for distal arthrogryposis type 2B. Am. J. Hum. Genet. 2003, 73, 212. [CrossRef] [PubMed]

15. Singh, A.K.; Singh, M.K.; Singh, V.; Singh, R.; Raghuvanshi, T.; Singh, C. Debilitation in tomato (Solanum lycopersicum L.) as result of heat stress. J. Pharmacogn. Phytochem. 2017, 6, 1917-1922.

16. Camejo, D.; Rodríguez, P.; Morales, M.A.; Dell'Amico, J.M.; Torrecillas, A.; Alarcón, J.J. High temperature effects on photosynthetic activity of two tomato cultivars with different heat susceptibility. J. Plant Physiol. 2005, 162, 281-289. [CrossRef]

17. Driedonks, N. From Flower to Fruit in the Heat-Reproductive Thermotolerance in Tomato and Its Wild Relatives. Ph.D. Thesis, Radboud University Nijmegen, Nijmegen, The Netherlands, 2018.

18. Raja, M.M.; Vijayalakshmi, G.; Naik, M.L.; Basha, P.O.; Sergeant, K.; Hausman, J.F.; Khan, P.S.S.V. Pollen development and function under heat stress: From effects to responses. Acta Physiol. Plant. 2019, 41, 1-20. [CrossRef]

19. Alsamir, M.; Mahmood, T.; Trethowan, R.; Ahmad, N. An overview of heat stress in tomato (Solanum lycopersicum L.). Saudi J. Biol. Sci. 2021, 28, 1654. [CrossRef]

20. Grover, A.; Mittal, D.; Negi, M.; Lavania, D. Generating high temperature tolerant transgenic plants: Achievements and challenges. Plant Sci. 2013, 205, 38-47. [CrossRef] 
21. Lin, Y.-X.; Jiang, H.-Y.; Chu, Z.-X.; Tang, X.-L.; Zhu, S.-W.; Cheng, B.-J. Genome-wide identification, classification and analysis of heat shock transcription factor family in maize. BMC Genom. 2011, 12, 76. [CrossRef]

22. Czarnecka-Verner, E.; Yuan, C.-X.; Fox, P.C.; Gurley, W.B. Isolation and characterization of six heat shock transcription factor cDNA clones from soybean. Plant Mol. Biol. 1995, 29, 37-51. [CrossRef]

23. Guo, J.; Wu, J.; Ji, Q.; Wang, C.; Luo, L.; Yuan, Y.; Wang, Y.; Wang, J. Genome-wide analysis of heat shock transcription factor families in rice and Arabidopsis. J. Genet. Genom. 2008, 35, 105-118. [CrossRef]

24. Döring, P.; Treuter, E.; Kistner, C.; Lyck, R.; Chen, A.; Nover, L. The role of AHA motifs in the activator function of tomato heat stress transcription factors HsfA1 and HsfA2. Plant Cell 2000, 12, 265-278. [CrossRef] [PubMed]

25. Kotak, S.; Port, M.; Ganguli, A.; Bicker, F.; Von Koskull-Döring, P. Characterization of C-terminal domains of Arabidopsis heat stress transcription factors (Hsfs) and identification of a new signature combination of plant class A Hsfs with AHA and NES motifs essential for activator function and intracellular localization. Plant J. 2004, 39, 98-112. [CrossRef] [PubMed]

26. Shim, D.; Hwang, J.-U.; Lee, J.; Lee, S.; Choi, Y.; An, G.; Martinoia, E.; Lee, Y. Orthologs of the class A4 heat shock transcription factor HsfA4a confer cadmium tolerance in wheat and rice. Plant Cell 2009, 21, 4031-4043. [CrossRef]

27. Takayama, K.; Tsutsumi, S.; Katayama, S.; Okayama, T.; Horie-Inoue, K.; Ikeda, K.; Urano, T.; Kawazu, C.; Hasegawa, A.; Ikeo, $\mathrm{K}$. Integration of cap analysis of gene expression and chromatin immunoprecipitation analysis on array reveals genome-wide androgen receptor signaling in prostate cancer cells. Oncogene 2011, 30, 619-630. [CrossRef]

28. Zhu, X.; Thalor, S.K.; Takahashi, Y.; Berberich, T.; Kusano, T. An inhibitory effect of the sequence-conserved upstream openreading frame on the translation of the main open-reading frame of HsfB1 transcripts in Arabidopsis. Plant Cell Environ. 2012, 35 2014-2030. [CrossRef]

29. Song, X.; Liu, G.; Duan, W.; Liu, T.; Huang, Z.; Ren, J.; Li, Y.; Hou, X. Genome-wide identification, classification and expression analysis of the heat shock transcription factor family in Chinese cabbage. Mol. Genet. Genom. 2014, 289, 541-551. [CrossRef]

30. Yang, Z.; Wang, Y.; Gao, Y.; Zhou, Y.; Zhang, E.; Hu, Y.; Yuan, Y.; Liang, G.; Xu, C. Adaptive evolution and divergent expression of heat stress transcription factors in grasses. BMC Evol. Biol. 2014, 14, 147. [CrossRef] [PubMed]

31. Ro, S.; Chea, L.; Ngoun, S.; Stewart, Z.P.; Roeurn, S.; Theam, P.; Lim, S.; Sor, R.; Kosal, M.; Roeun, M. Response of tomato genotypes under different high temperatures in field and greenhouse conditions. Plants 2021, 10, 449. [CrossRef]

32. Ayenan, M.A.T.; Danquah, A.; Hanson, P.; Asante, I.K.; Danquah, E.Y. Identification of new sources of heat tolerance in cultivated and wild tomatoes. Euphytica 2021, 217, 1-16. [CrossRef]

33. Ayenan, M.A.T.; Danquah, A.; Hanson, P.; Asante, I.K.; Danquah, E.Y. Tomato (Solanum lycopersicum L.) Genotypes Respond Differently to Long-Term Dry and Humid Heat Stress. Horticulturae 2022, 8, 118. [CrossRef]

34. Scharf, K.-D.; Rose, S.; Zott, W.; Schöffl, F.; Nover, L.; Schöff, F. Three tomato genes code for heat stress transcription factors with a region of remarkable homology to the DNA-binding domain of the yeast HSF. EMBO J. 1990, 9, 4495-4501. [CrossRef]

35. Morimoto, R. Cells in stress: Transcriptional activation of heat shock genes. Science 1993, 259, 1409-1411. [CrossRef]

36. Neta-Sharir, I.; Isaacson, T.; Lurie, S.; Weiss, D. Dual role for tomato heat shock protein 21: Protecting photosystem II from oxidative stress and promoting color changes during fruit maturation. Plant Cell 2005, 17, 1829-1838. [CrossRef]

37. Sun, W.; Van Montagu, M.; Verbruggen, N. Small heat shock proteins and stress tolerance in plants. Biochim. Biophys. Acta BBA Gene Struct. Expr. 2002, 1577, 1-9. [CrossRef]

38. Sun, W.; Bernard, C.; Van De Cotte, B.; Van Montagu, M.; Verbruggen, N. At-HSP17. 6A, encoding a small heat-shock protein in Arabidopsis, can enhance osmotolerance upon overexpression. Plant J. 2001, 27, 407-415. [CrossRef] [PubMed]

39. Lee, G.J.; Vierling, E. A small heat shock protein cooperates with heat shock protein 70 systems to reactivate a heat-denatured protein. Plant Physiol. 2000, 122, 189-198. [CrossRef] [PubMed]

40. Yang, X.; Zhu, W.; Zhang, H.; Liu, N.; Tian, S. Heat shock factors in tomatoes: Genome-wide identification, phylogenetic analysis and expression profiling under development and heat stress. Peer] 2016, 4, e1961. [CrossRef] [PubMed]

41. Waters, E.R. The evolution, function, structure, and expression of the plant sHSPs. J. Exp. Bot. 2013, 64, 391-403. [CrossRef] [PubMed]

42. Basha, E.; O'Neill, H.; Vierling, E. Small heat shock proteins and $\alpha$-crystallins: Dynamic proteins with flexible functions. Trends Biochem. Sci. 2012, 37, 106-117. [CrossRef] [PubMed]

43. Goh, C.H.; Nam, H.G.; Park, Y.S. Stress memory in plants: A negative regulation of stomatal response and transient induction of rd22 gene to light in abscisic acid-entrained Arabidopsis plants. Plant J. 2003, 36, 240-255. [CrossRef] [PubMed]

44. Arce, D.; Spetale, F.; Krsticevic, F.; Cacchiarelli, P.; De Las Rivas, J.; Ponce, S.; Pratta, G.; Tapia, E. Regulatory motifs found in the small heat shock protein (sHSP) gene family in tomato. BMC Genom. 2018, 19, 860. [CrossRef]

45. Marko, D.; El-Shershaby, A.; Carriero, F.; Summerer, S.; Petrozza, A.; Iannacone, R.; Schleiff, E.; Fragkostefanakis, S. Identification and characterization of a thermotolerant TILLING allele of heat shock binding protein 1 in tomato. Genes 2019, 10, 516. [CrossRef] [PubMed]

46. Fu, S.; Meeley, R.; Scanlon, M.J. Empty pericarp2 encodes a negative regulator of the heat shock response and is required for maize embryogenesis. Plant Cell 2002, 14, 3119-3132. [CrossRef] [PubMed]

47. Fu, S.; Rogowsky, P.; Nover, L.; Scanlon, M.J. The maize heat shock factor-binding protein paralogs EMP2 and HSBP2 interact non-redundantly with specific heat shock factors. Planta 2006, 224, 42-52. [CrossRef] [PubMed]

48. Rana, R.M.; Dong, S.; Tang, H.; Ahmad, F.; Zhang, H. Functional analysis of OsHSBP1 and OsHSBP2 revealed their involvement in the heat shock response in rice (Oryza sativa L.). J. Exp. Bot. 2012, 63, 6003-6016. [CrossRef] [PubMed] 
49. Knapp, S.; Consortium, T.G. The tomato genome sequence provides insights into fleshy fruit evolution. Res. Lett. 2012, 485, 635-641.

50. Giorno, F.; Wolters-Arts, M.; Grillo, S.; Scharf, K.-D.; Vriezen, W.H.; Mariani, C. Developmental and heat stress-regulated expression of HsfA2 and small heat shock proteins in tomato anthers. J. Exp. Bot. 2010, 61, 453-462. [CrossRef]

51. Fragkostefanakis, S.; Mesihovic, A.; Simm, S.; Paupière, M.J.; Hu, Y.; Paul, P.; Mishra, S.K.; Tschiersch, B.; Theres, K.; Bovy, A. HsfA2 controls the activity of developmentally and stress-regulated heat stress protection mechanisms in tomato male reproductive tissues. Plant Physiol. 2016, 170, 2461-2477. [CrossRef]

52. Frank, G.; Pressman, E.; Ophir, R.; Althan, L.; Shaked, R.; Freedman, M.; Shen, S.; Firon, N. Transcriptional profiling of maturing tomato (Solanum lycopersicum L.) microspores reveals the involvement of heat shock proteins, ROS scavengers, hormones, and sugars in the heat stress response. J. Exp. Bot. 2009, 60, 3891-3908. [CrossRef]

53. Hsu, S.-F.; Lai, H.-C.; Jinn, T.-L. Cytosol-localized heat shock factor-binding protein, AtHSBP, functions as a negative regulator of heat shock response by translocation to the nucleus and is required for seed development in Arabidopsis. Plant Physiol. 2010, 153, 773-784. [CrossRef]

54. Al-Gaadi, K.A.; Tola, E.; Madugundu, R.; Fulleros, R.B. Sentinel-2 images for effective mapping of soil salinity in agricultural fields. Curr. Sci. 2021, 121, 384.

55. Pathak, T.B.; Stoddard, C.S. Climate change effects on the processing tomato growing season in California using growing degree day model. Modeling Earth Syst. Environ. 2018, 4, 765-775. [CrossRef]

56. Scholberg, J.; McNeal, B.L.; Boote, K.J.; Jones, J.W.; Locascio, S.J.; Olson, S.M. Nitrogen stress effects on growth and nitrogen accumulation by field-grown tomato. Agron. J. 2000, 92, 159-167. [CrossRef]

57. Sturn, A.; Quackenbush, J.; Trajanoski, Z. Genesis: Cluster analysis of microarray data. Bioinformatics 2002, 18, 207-208. [CrossRef] [PubMed] 